\title{
Identifying Difficulties Encountered by Indonesian EFL Learners in Oral Presentation
}

\author{
Kheryadi $^{1}$, Fitri Hilmiyati ${ }^{2}$ \\ Universitas Islam Negeri Sultan Maulana Hasanuddin Banten, Indonesia \\ Correspondence: $\quad$ Kheryadi, Universitas Islam Negeri Sultan Maulana Hasanuddin Banten, Indonesia. \\ email: kheryadi@uinbanten.ac.id \\ Submitted: Augustus 08, 2020 \\ Revised: February 22, 2021 \\ Accepted: March 23, 2021 \\ DOI: $10.29408 /$ veles.v5i1.2486 \\ URL: http://dx.doi.org/10.29408/veles.v5i1.2486
}

\begin{abstract}
This study investigates areas of oral presentation difficulties experienced by students at English Education Department of Universitas Islam Negeri Sultan Maulana Hasanuddin Banten. The method used was the case study approach. The participants of this study are the fifth semester of English Education Department. The data were gathered through questionnaires and interviews. Findings from the data analysis show that a significantly prominent matter faced by the students in doing a presentation is the explanation aspect and Self-control, getting nervous and unconfident.
\end{abstract}

Keywords: EFL oral class presentation, dominant problems, self-control.

\section{Introduction}

Oral presentation becomes one of the communication competencies that should be carried out by the students. Oral presentation is a conversation with message frequently given to / from an audience by a presenter with the aid of audiovisual equipment aimed at encouraging, invigorating, stimulating, teaching, angering or entertaining. Almost every lecturer uses oral presentation as their appraisal criterion in the college. Oral presentation looks like an easy task because we're just talking before the class and making sure the audience knows the content. Otherwise, the most difficult task in language teaching for most teachers is to improve oral communication skills. as supported by (van Ginkel et al., 2017), learners must be able not only to communicate but also to connect. Živković, (2014) adds that students need a great deal of opportunity to communicate their needs to connect with the demands of the globalization era, graduates need to have oral communication skills to work well in their professional environment.

According to (Stan Van Ginkel \& Judith Gulikers, 2015) a number of factors impacts: Competition; Students worry about errors, fear criticism, or are shy. Nothing to note; Students have nothing to say. Lamentably low involvement; Only one person may speak at a time, as big classes and high participation rates create noisy classrooms. 
Therefore, there must be a way to anticipate all of these things. A new set of activities is incorporated into the classroom that focuses on the transmission of meaning rather than on the language itself. (Hyland, (2014); Erickson et al., (2015). Girard et al., (2011) suggests that students should spend more time analyzing the expression, and less on the way they say it. They are capable of speaking a large number of languages. learners may engage in two verbal communication tasks: oriented communication and distracted communication. All of these activities include learners in the implementation of language actively rather than speaking. They plan to improve foreign language skills through constant contact. Through the use of human communication, human constructs may be incorporated into the artistic framework that expresses meaning (Clayton et al., 2013).

Sofiana et al., (2019) argued that some teachers inhibit their students to display L1-like behavior. Regardless, this can lead to problems with speaking. This is because learning a second language requires exceptional opportunities for using it. Furthermore, it suggests that English is not a language worth communicating in. Learners view the language as assigned to nonessential conversational or classroom activities, while the mother language remains the acceptable means to address urgent issues. Vocabulary and/or grammar skills were essential to many instructor's strategies. While they disagree with L1, L2's practice does not reflect this (Gogunskaya, (2015); Namaziandost et al., (2019); Herbein et al., (2018).

Meanwhile, (Hyland, 2014) discovered that various factors should be considered in order for EFL students to be able to communicate in English. The students themselves remain interested in and wish to continue these subjects. For instance, many learners lack the prerequisite vocabulary to comprehend their content and cannot communicate further. Insufficient strategic competence and communication capabilities may be one of the additional factors that prevents a union from proceeding. Communication will only be established if students are inspired and willing to being exposed to their personality and work with others (Girard et al., (2011).

Furthermore, Self-confidence is having a consideration deciding the ability of the learners to take part in oral activities in language classrooms (Hwa, 2010). In other terms we may assume there will be good communication where there is self-confidence. On the other hand, the most dangerous obstacle to effective communication is thought to be lack of self-confidence. Numerous studies have been conducted on the impact of self-confidence on the readiness of learners to engage in communication practices in the classroom (Donald Ary, 2011) Particularly, the aims of this study are to know how students plan their communication in delivering material in front of the class, also seeks the problems and difficulties encountered by them. To have them take further steps as said by (Gogunskaya, 2015), Students require comprehensive, in-depth training and practice for effective oral communication. Oral presentation skills are essential for employability and actual academic study, as they direct learners into some discourse and persistent thought (Raento, A, 2015) As the title itself states, informative speeches merely aim at educating a target group about specific subjects. The present study will contribute in explaining the obstacles faced by students in making presentations in front of the class, in this case, the research provides an overview for students and lecturers to overcome students who feel that they 
are less confident in making presentation. The novelty of this research lies in the utilization of factors and aspects of students who lack confidence in speaking in front of the class. At the end of this, students can apply their linguistic knowledge to speak. Hence, some research questions are posed as follows: 1. What are factors that causes of poor performance in English oral presentation among Students of English Education Department in the classroom? 2. In what extent do the students feel difficult in conveying the material?

\section{Method}

A case study was employed in this study. In this regard, the qualitative data attempts to gain information about a case of a subject. The case of this research is students' difficulties in English oral presentation. Moreover, the rationale for using such a method was based on the research questions proposed. In this case, the first question concerned on factors that causes of poor performance in English oral presentation among Students and the second question deal with In what extent do the students feel difficult in conveying the material. These were garnered through questionnaire and interview.

\subsection{Participants}

The subjects participating in this study were the fifth semester of English Education Study Program in Universitas Islam Negeri Sultan Maulana Hasanuddin Banten. There were ninetyfive students involved. The researcher concerned on students' behavior in oral presentation.

\subsection{Data collection}

Two types of instruments, i.e. questionnaire and interview were employed. In this case, the questionnaires used in this study comprised the demographic questionnaire, the questionnaire assessing the quality of the student's oral presentation. The first one was developed from the constructs advocated by (Herbein et al., 2018), the second one was adapted from Hyland's work (Hyland, 2014), Meanwhile, the interview was utilized to ensure the data obtained from the questionnaire.

\subsection{Data analysis}

The data was analyzed based on the observation sheet and interview. Several steps were taken in analyzing the data: 1 . During the presentation, the researcher made a note based on the observation sheet. 2. After displaying the data in detail, the researcher compared it against the criteria of success. 3. The researcher make conclusion. The researcher observed all of the student activity during the class presentation but the researcher focused on the several aspects. The activity that used during the class analyzed by the researcher by following these factors; preparation, linguistic, and non-linguistic. Each factor has their aspects. In preparation there are two aspects; Good understanding topic, and preparing visual aid. In Linguistic there are three aspects; Grammar, Vocabulary and Pronunciation. The last is non-linguistic, it has two aspects; Self-confident, and Anxiety. 


\section{Results and Discussion}

\subsection{Results}

There are two facets of the training: good understanding of the subject and the preparation of visual assistance. There are three facets of linguistics: grammar, vocabulary and pronunciation. The second is non-linguistic, has two aspects: self-confident, and anxiety. The result of the observation will suggest the most complex factors and aspects that occur in the class presentation, the observational outcome results are summarized in these charts.

Chart 1. Preparation

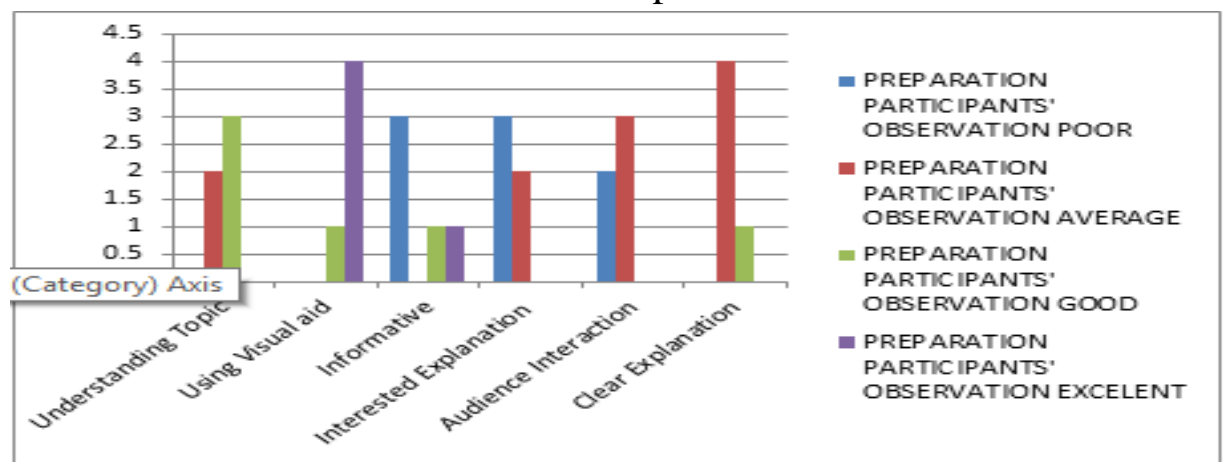

This preparation chart showed that the most aspect that got poor is in an informative and exciting explanation. It means conveying the participants have an inadequate explanation, especially in informative and exciting explanation. It could make the presentation is not clear for the audience; even they have mastered the topic, they still confuse how to present the topic well, they only explain, but the explanation was not satisfying.

Chart 2. Linguistic

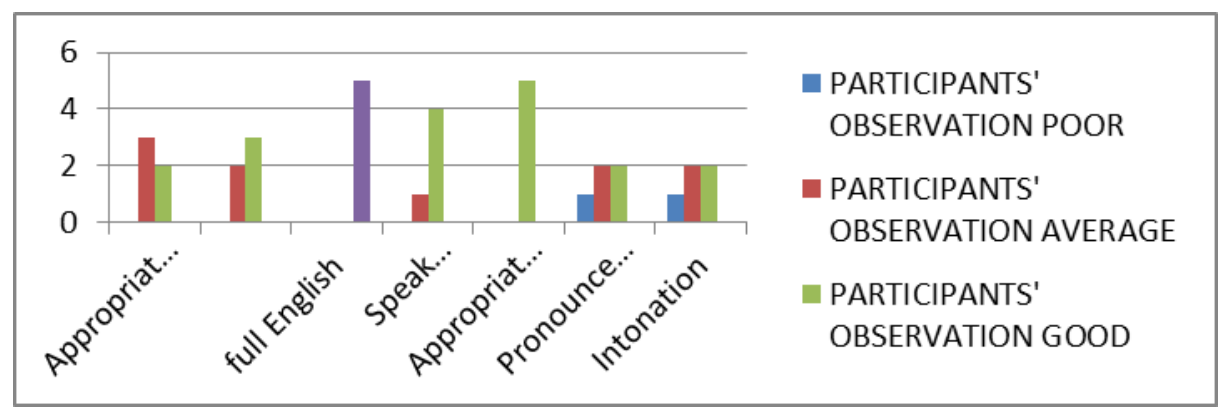

In linguistic aspect, the participants who got poor are only in the pronunciation. The next aspect that got most average value is in grammar and pronunciation. Pronunciation could make the explanation not clear because of the intonation and pronoun. 


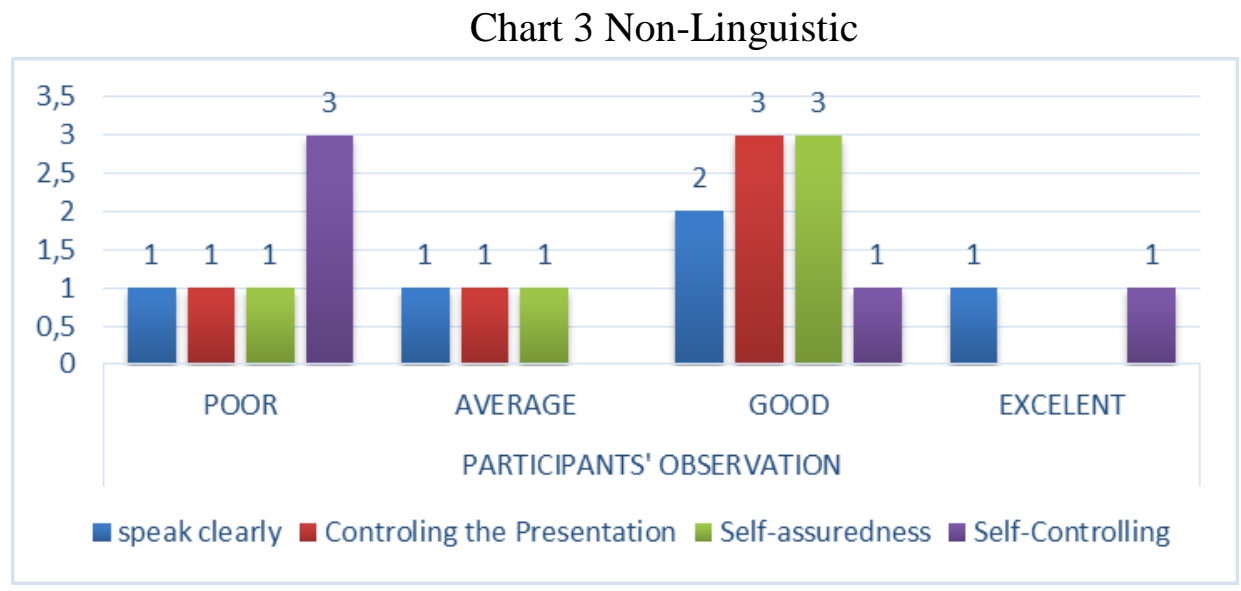

Based on the above results, participants were shown to have poor self-control, worry about making a mistake and also felt nervous when performing. Nevertheless, they keep controlling the presentation run well.

Furthermore, Interview is the second instrument that used by the researcher in conducting the data. The interview was hold after the observation' conducted. There are seven questions were asked to the participants. The questions are done by interviewing directly to all of the participants. This instrument is to support the observation data and to make sure what the students feel during the presentation also to gain more data for the research. Based on the interview result, the researcher asked 6 questions to the audience.

a) What factors can make your presentation is bad during English presentation?

Based on the interview the most factor that can make the presentation bad is less of preparation. They lack of preparation than confuse when present the topic, sometimes they got anxious and lack of confident when spoke in front the class. One participant stated that "My heart is running fast when presentation, then feel my presentation isn't good enough and less of mastering the topic" it means they not ready for the presentation.

b) Why you use Indonesian language when presenting English course?

The first it is accidentally spoken in presentation, and the second is they don't know the vocabulary and worrying if the audience will not understand the topic. Based on the answer the researcher can make a conclusion if they got nervous and lack of vocabulary because of the situation in front of the class

c) Are you always worrying about grammar before speak?

Three of participants said grammar is important, if have good grammar the presentation will also good. They are worrying if the grammar was wrong. The participants seem feel worry for getting criticism from their friends or their teacher.

d) Is your pronunciation can influence the presentation?

There are varieties of answer for the question. One student answered that if my pronunciation good my confident will be improved. And some participant said that don't care about the presentation the main point is the audience understand the topic well. So 
based on this answer pronunciation is not really important for the presentation but it can be influenced the self- confident when they thinking about it.

e) What did you feel when explain the material in front of your classmate?

All of the participants answered that they feel not confident and nervous when the have to speak in front their friends. It made the presentation run not well, and not focus in conveying the topic.

f) Are you worrying if your presentation isn't clear?

They worried about making mistake in the presentation. They got nervous. One participant stated "I very worry if my presentation is not clear, because of my preparation and less confident". They always thinking" is it my presentation clear?" it made they loss of self-confident. Are you scared about making mistake in talking English?

\subsection{Discussion}

Based on the aforementioned results, the researcher used the details to be analyzed in order to ascertain what were difficult and easy element in students' oral presentation.

\section{Participant 1}

Preparation: Based on the observation, the first participant is well trained. The participant knows the subject well and addresses the subject using visual aid such as Microsoft PP. In presenting the subject the participant looks at the subject well, the participant describes the subject simply without having any difficulties, when presenting the visual aid P1 presented the subject attractively. Then for the next element of the explanation, but the first person has a weak connection. The participant clarified that the subject just reads the Microsoft Power Point slide, that P1 had no connection with the crowd, that the response was too bland, no body language, no eye contact. P1 when reading the topic on the power point slide, P1 even reads the topic as fast as it makes the presentation go fast.

Linguistic: In linguistic terms, there are three factors in linguistic grammar, vocabulary and pronunciation. The first element that the researcher found in linguistics is that of grammar, based on observation, P1 has a good grammar in speaking and describing the subject, P1 uses acceptable grammar in any sentence, good tenses, good structure. The second element is vocabulary, based on observation, as long as the presentation P1 often uses English to express the subject, but P1 also reads the slides and notes. Not only does it use English to express the subject, but $\mathrm{P} 1$ has also used sufficient vocabulary and spoken fluently, making it easier for the viewer to understand what P1 has explained. Based on the observation that P1 spoke in front of the class, P1 spoke easily, but in every word P1 spoke plainly. Pronouncing the word is really necessary in English, if the pronunciation is wrong, the listener can't understand the word, but on the other hand, P1 has a poor intonation in describing the material.

Non-Linguistic: The last element the researcher observed is non-linguistic, there are many aspects of non-linguistic, self-confident, and anxiety. Based on the impression and video taken, P1 seems so anxious, one of the signature nervous characteristics is that P1 can't 
regulate the presentation, P1 talks too easily, and just reads the slide. P1 doesn't care about the $\mathrm{P} 1$ audience just concentrate on the subject, which means that P1 doesn't know whether or not the audience gets it. No contact with the body, no contact with the ears, just stay in one position. Based on the observation, P1 has a poor regulation of the emotions.

\section{Participant 2}

Preparation: The second participant has poor mastery of the subject in preparation, P2 frequently forgets the subject than gets lost in describing the subject, but conveniently P2 used and prepared the media well. It based on her note in the presentation of the subject P2. P2 seems unnoticed by the viewer, no eye contact or body language activity, but P2 has a plain enough description. In presenting the subject still P2 has no involvement P2 has a nice intonation and the voice makes the introduction plain enough, but the situation of the class was too dull.

Linguistic: The participant also used full English based on the table P2 "good" suitable tense, not only using good tense, but also in describing the subject. Overall, P2 has no major problem only in pronunciation and intonation in the linguistic aspect, and often the intonation used by P2 was not simple.

Non-Linguistic: Based on the observation, P2 appears nervous in this factor P2, P2 often shakes the body of P2 in conveying the subject. Based on table 4.2, P2 was weak in selfassurance and as long as the $\mathrm{P} 2$ presentation run seems nervous, it can be seen when $\mathrm{P} 2$ often failed to explain P2 and often can't manage P2 itself. It did not make the reason plain enough.

\section{Participant 3}

Preparation: In almost every way, P3 was perfect for the preparation. P3 was very informative in describing the subject, P3 explained the subject in depth and steadily made it possible for the viewer to grasp the subject. The reason was so simple, not only those who normally use the body language well, but also P3 who have strong student engagement. P3 seemed to have mastered the subject very well and praised the presentation.

Linguistic: P3 has strong intonation in the linguistic aspect, not to fast, but also not to slow. It was almost perfect. Strong spelling, excellent grammar. But P3 still confuses often in shaping the word. Overall, P3 has outstanding vocabulary, which made the presentation plain enough for the viewer.

Non-Linguistic: Non-linguistic, self-confident and anxiety have 2 components. Based on the report, P3 has outstanding self-confidence and anxiety. P3 manages the presentation well. P3 was excellent for self-controlling, so P3 was very prepared and loved the presentation.

\section{Participant 4}

Preparation: For the presentation, P4 has sufficient media to assist. P4 was too flat in the description segment. Since P3 concentrated on the slide and the note, the subject that P3 
explained was so dull. Often, in illustrating, P3 used her side. Less touch and less body language with the viewer.

Linguistic: Full English is used in linguistic P4, which means that P4 is still positive and believed in itself, even $\mathrm{P} 4$ has poor intonation and $\mathrm{P} 4$ pronunciation continues to use English. There is no issue with the syntax of P4, but the reason was not clear enough since P4 does not speak fluently. In conveying the subject, P4 often stuttered.

Non-Linguistic: P4 feels insufficiently secure. It can be seen from the participant's expression. P4 stuttered at times, but P4 was also able to monitor the presentation. For the anxiety component, P4 was average, especially in self-control.

\section{Participant 5}

Preparation: P5 has good preparation on the basis of observation. During the introduction, P5 prepared the public. The participant clarified the subject well. The subject was perfected by the participant in conveying the subject, the participant specifically describes the subject without having any difficulties, the last participant has strong contact with the audience, P5 not only focused on the slide or the note but also focused on the audience. P5 has sometimes developed a body language for simple clarification. P5 spoke softly to ensure that the listener heard what P5 had said. It made it run smoothly for the presentation.

Linguistic: sufficient grammar in the sentence was used in addressing the subject P5, strong tenses. The second element is language, based on intuition, as long as P5 still used English to express the information in the introduction. P1 spoke softly and yet spoke fluently with ample vocabulary, making it possible for the viewer to grasp what P5 explained. P5 has strong intonation, based on the fact that P1 speaks in front of the class.

Non-Linguistic: The last person is secure in himself. The appearance could be managed very well by P5, it also has strong self-control. Non-linguistic elements may impact others. P5 has no problem with fear and self-confidence in this case.

Apart from these approaches the respondents also suggested that watching other people's presentations and learning from their own past mistakes would enable them to make a good presentation.

\section{Conclusion}

Several factors can cause difficulties in an oral presentation. Getting nervous in front of the class is normal, even for a skilled speaker, so media or visual assistance is so crucial that they can help with their presentation. Preparing the media and the subject will make the presentation more accessible. It can also improve self-confidence and reduce nervousness when speaking in front of the class. More analysis is required to assess other presentation skills in order to achieve more intelligible outcomes.

\section{References}

Clayton, J. M., Butow, P. N., Back, A. L., Laidsaar-Powell, R. C., Waters, A., O’brien, A., Boyle, F., Arnold, R. M., Tulsky, J. A., \& Tattersall, M. H. (2013). Evaluation of a novel 
individualised communication-skills training intervention to improve doctors' confidence and skills in end-of-life communication. Palliative Medicine, 27(3), 236-243. https://doi.org/10.1177/0269216312449683

Devriendt, B., De Geest, B. G., \& Cox, E. (2011). Designing oral vaccines targeting intestinal dendritic cells. Expert Opinion on Drug Delivery, 8(4), 467-483. https://doi.org/10.1517/17425247.2011.561312

Donald Ary. (2011). Introduction to research in education (USA: Wadsworth Group A Division Of Thomson Learning Inc, 2002),426.

Erickson, J. M., Blackhall, L., Brashers, V., \& Varhegyi, N. (2015). An interprofessional workshop for students to improve communication and collaboration skills in end-of-life care. American Journal of Hospice and Palliative Medicine, 32(8), 876-880. https://doi.org/10.1177/1049909114549954

Girard, T., State, P., Musa Pinar, A., \& Trapp, P. (2011). An exploratory study of class presentations and peer evaluations: do students perceive the benefits? In Academy of Educational Leadership Journal (Vol. 15, Issue 1).

Gogunskaya, V. (2015). Powerful presentations developing practical guidebook for students. https://www.theseus.fi/handle/10024/99981

Herbein, E., Golle, J., Tibus, M., Zettler, I., \& Trautwein, U. (2018). Putting a speech training program into practice: Its implementation and effects on elementary school children's public speaking skills and levels of speech anxiety. Contemporary Educational Psychology, 55, 176-188. https://doi.org/10.1016/j.cedpsych.2018.09.003

Hwa, J. K.-D. (2010). Preparing EFL learners for oral presentations. Iteslj.Org. http://iteslj.org/Lessons/King-PublicSpeaking

Hyland, F. (2014). Open learning: the journal of open, distance and e-learning providing effective support: investigating feedback to distance language learners. October 2014, $37-$ 41. https://doi.org/10.1080/02680510120084959

Ledford, Bruce R.; Sleeman, P. J. (2013). Instructional design: systems strategies. ISBN-1931576-82-3.

Namaziandost, E., Neisi, L., Kheryadi, \& Nasri, M. (2019). Enhancing oral proficiency through cooperative learning among intermediate EFL learners: English learning motivation in focus. Cogent Education, 6(1). https://doi.org/10.1080/2331186X.2019.1683933

Raento, A, O.-. (2015). Designing for privacy and self-presentation in social awareness. Springer. https://link.springer.com/content/pdf/10.1007/s00779-008-0200-9.pdf

Richard Miles. (2013). Issues related to teaching oral presentations in japanese universities. In N. Sonda \& A. Krause (Eds.), JALT2013 Conference Proceedings. Tokyo: JALT.

Richards, J. C. (2008). Teaching listening and speaking from theory to practice. www.cambridge.org

Sofiana, N., Mubarok, H., \& Yuliasri, I. (2019). English language teaching in secondary schools: An analysis of the implementation of Indonesian ELT 2013 curriculum. International Journal of Instruction, 12(1), 1533-1544. https://doi.org/10.29333/iji.2019.12198a 
Stan Van Ginkel, Judith Gulikers, H. B. (2015). The impact of the feedback source on developing oral presentation competence: Studies in Higher Education. https://srhe.tandfonline.com/doi/abs/10.1080/03075079.2015.1117064\#.X-wWG9gzbDc

van Ginkel, S., Gulikers, J., Biemans, H., \& Mulder, M. (2017). The impact of the feedback source on developing oral presentation competence. Studies in Higher Education. https://doi.org/10.1080/03075079.2015.1117064

Živković, S. (2014). The Importance of oral presentations for university students. Mediterranean $\begin{array}{lllll}\text { Journal of } & \text { Social } & \text { Sciences, } & 5(19), & 468 .\end{array}$ http://www.richtmann.org/journal/index.php/mjss/article/view/4278 